\title{
PEMANFAATAN HASIL PENELITIAN SITUS GUNUNG WINGKO
}

\section{UTILISATION OF RESEARCH IN GUNUNG WINGKO SITE}

\author{
Alifah \\ Balai Arkeologi Yogyakarta \\ alifah.ali@gmail.com
}

\begin{abstract}
Gunung Wingko is one of the Bronze Age sites located in Bantul Regency or approximately $25 \mathrm{~km}$ south from Yogyakarta city and $1.5 \mathrm{~km}$ from Indian Ocean coastline. This site became known in 1972, and since then an intensive research had been conducted there, surveys as well as excavations. Information related to the Gunung Wingko community life reconstruction has been obtained from the research. However, nowadays the site seemed to be forgotten within the contexts of historical reconstruction, in particular by the community of Yogyakarta and its nearby surrounding. The fast change of land use has caused damage to the site research has provided some culture information but in the other hand the management and utilization of the research results are still minimal. In this paper will be discussed how to utilize result in Gunung Wingko site based on conservation efforts. The Results of this paper are expected to be used as a reference to managing the site.
\end{abstract}

Keywords : research, utilization, Gunung Wingko sites

\begin{abstract}
ABSTRAK
Situs Gunung Wingko merupakan salah satu situs protohistori yang terletak di Kabupaten Bantul atau kurang lebih $25 \mathrm{~km}$ sebelah selatan dari kota Yogyakarta dan 1,5 km dari garis pantai Samudera Hindia. Situs ini mulai dikenal pada tahun 1972 dan sejak saat itu upaya penelitian secara intensif terus dilakukan baik berupa survei maupun ekskavasi. Berbagai informasi yang berkaitan dengan rekonstruksi kehidupan masyarakat pendukung Situs Gunung Wingko telah diperoleh dari upaya penelitian tersebut. Namun saat ini kondisi Situs Gunung Wingko seolah terlupakan dalam rekonstruksi sejarah terutama bagi masyarakat Yogyakarta dan sekitarnya. Tingginya pengalihan lahan telah merusak keberadaan situs. Penelitian yang dilakukan telah memberikan banyak informasi budaya, namun pengelolaan dan pemanfaatan hasil penelitian masih belum maksimal. Tulisan ini berupaya untuk membahas bagaimana upaya pemanfaatan hasil penelitian di Situs Gunung Wingko yang berbasis pada upaya pelestarian. Hasil tulisan ini diharapkan dapat dimanfaatkan sebagai salasatu referensi dalam pengelolaan situs.
\end{abstract}

Kata kunci: Hasil Penelitian, Pemanfaatan, Situs Gunung Wingko 


\section{PENDAHULUAN}

Situs Gunung Wingko merupakan salah satu situs pemukiman masa protohistori. Gunung Wingko merupakan nama dari desa kuno yang saat ini telah berubah nama menjadi Desa Tegalrejo. Penamaan Situs Gunung Wingko berasal dari sebaran temuan fragmen gerabah yang sangat melimpah di tempat ini. Wingko dalam bahasa Jawa berarti kereweng atau fragmen gerabah dan istilah gunung berarti gunung atau bukit sehingga Gunung Wingko merupakan bukit yang banyak mengandung temuan fragmen gerabah.

Situs Gunung Wingko terletak di areal perkampungan tepatnya di sebelah utara objek wisata Pantai Samas dan berada pada area seluas $2,88 \mathrm{~km}^{2}$ (Nitihaminoto 2001). Berada di desa Srigading dan desa Tirtohargo Kecamatan Sanden, Kabupaten Bantul. Situs Gunung Wingko berada pada lahan berpasir yang merupakan hasil pelapukan, erosi, dan deposisi batuan yang berasal dari aktivitas Gunung Merapi. Secara geomorfologi areal situs terletak pada dua satuan geomorfik, yaitu dataran aluvial pantai yang terdiri atas tiga satuan bentuk lahan yaitu beting gisik, cekungan antar beting dan gumuk pasir. Satuan geomorfik yang kedua adalah dataran fluvial sungai yang terdiri atas dataran banjir, dan tanggul alam. Situs Gunung Wingko terbentuk oleh barried island (garis penghalang) yang berangsur-angsur menjadi daratan (Suprajaka 1989). Daerah ini merupakan bukit pasir yang dikelilingi oleh laut. Bukit pasir tersebut mula-mula terbentuk dari pasir pantai yang berasal dari pantai yang dangkal dan materialnya terhempas oleh arus pantai. Pada perkembangannya barried island berkembang menjadi bukit pasir, dan daerah yang terhalang berubah menjadi laguna. Areal Situs Gunung Wingko merupakan daerah pengendapan sehingga selalu terjadi penambahan meterial dari proses sedimentasi baik oleh kegiatan fluvial, marin maupun aeolin (Suprajaka 1989).

\section{HASIL PENELITIAN ARKEOLOGI DI SITUS GUNUNG WINGKO}

Penelitian arkeologi di Situs

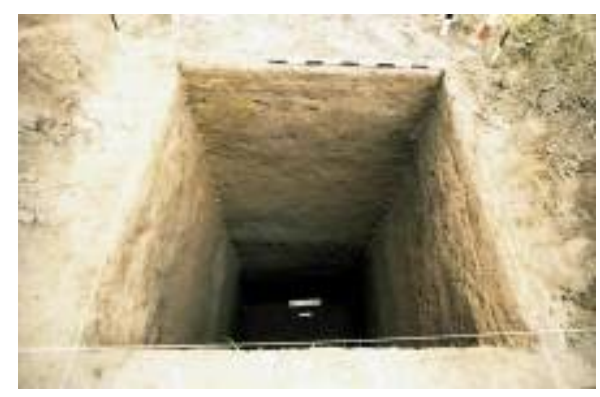

Foto 1. Salah satu kotak ekskavasi di Situs Gunung Wingko yang menunjukan lapisan stratigrafi tanah Dok. Balar YK

Gunung Wingko telah dilakukan secara intensif sejak tahun 1972 hingga tahun 1990an berupa survei dan ekskavasi yang dilakukan oleh Balai Arkeologi Yogyakarta (Nitihaminoto 2001).

Hasil penelitian arkeologi menghasilkan data artefaktual berupa temuan gerabah, keramik, alat besi, bandul jala, manik-manik, artefak perunggu, dan artefak tulang (lihat gambar 1). Selain artefak juga ditemukan ekofak berupa rangka manusia dan tulang binatang serta temuan featur kubur dan sisa perapian. Temuan-temuan ini telah memberi gambaran tentang budaya dan kehidupan masyarakat Situs Gunung Wingko saat itu.
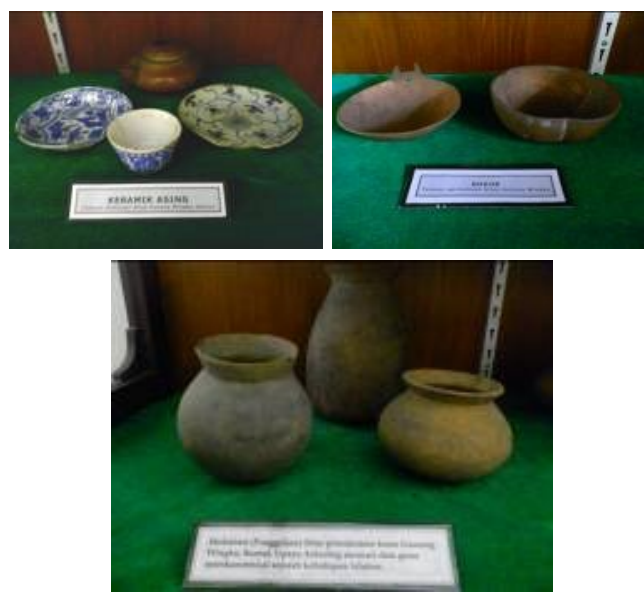

Gambar 1. Beberapa artefak dari Situs Gunung Wingko.

Dok. penulis 
Analisis pertanggalan absolut yang telah dilakukan menghasilkan pertanggalan $1990 \pm 90$ BP atau 2000 tahun yang lalu. Analisisi ini dilakukan terhadap sampel arang dan tulang yang ditemukan pada lapisan budaya yang paling bawah (tertua). Sementara pertanggalan dari lapisan budaya yang paling muda menghasilkan angka tahun $270 \pm 60$ B.P atau sekitar abad ke-17 (Nitihaminoto, 2005). Data ini menunjukan intensitas penghunian situs yang cukup panjang, yaitu dari rentang masa prasejarah hingga masa sejarah. Rentang waktu penghunian Situs Gunung Wingko yang cukup panjang ini telah melewati beberapa babak sejarah, diantaranya masa prasejarah akhir (perundagian) (Nitihaminoto 2001), masa Hindu-Budha, masa Islam dan masa Kolonial. Namun perkembangan babak sejarah yang terjadi ternyata tidak membawa pengaruh yang signifikan terhadap perkembangan kehidupan yang terjadi di situs tersebut. Rekonstruksi kehidupan masyarakat Situs Gunung Wingko berdasar dari data penelitian menunjukan bahwa masyarakat telah membentuk pemukiman menetap dangan variasi semi menetap. Selain itu masyarakat Gunung Wingko juga telah mengenal tata ruang dalam pola pemukiman mereka yaitu dengan adanya pembagian lahan untuk hunian dan penguburan (Nitihaminoto, 2005).

Bentuk subsistensi masyarakat Situs Gunung Wingko adalah bermatapencaharian utama sebagai pembuat garam. Interpretasi ini didukung oleh data etnografi (Nitihaminoto 2001) Selain mata pencaharian utama sebagai pembuat garam, masyarakat Gunung Wingko juga memiliki mata pencaharian sampingan sebagai pemelihara ternak, berburu, dan menangkap ikan. Selain itu masyarakat Situs Gunung Wingko juga melakukan aktivitas pembuatan anyaman dengan memanfaatkan sumberdaya yang tersedia di sekitar mereka. Interpretasi ini didasarkan pada adanya temuan hias tera yang ada dalam dasar gerabah yang sangat melimpah (lihat gambar 2) (Alifah 2012).
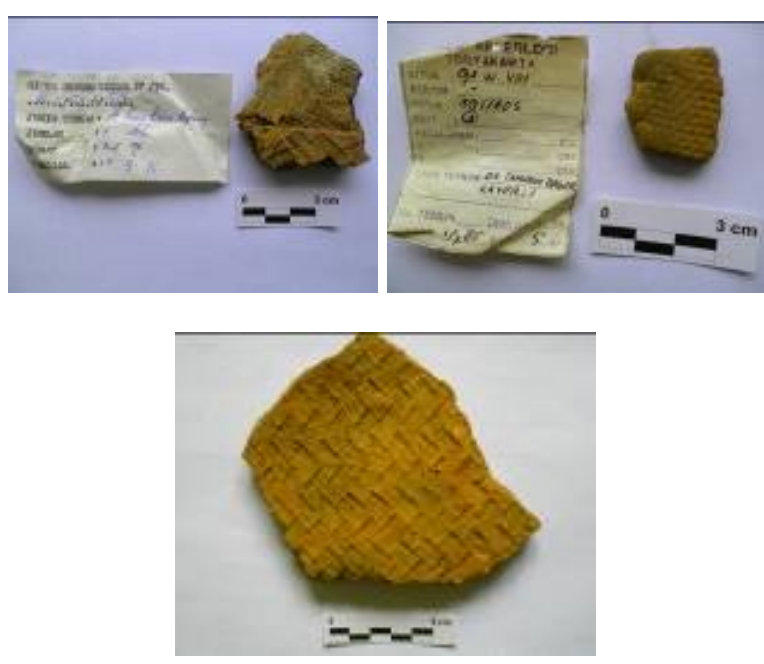

Gambar 2. Beberapa contoh hias tera pola anyaman yang terdapat pada dasar gerabah Gunung Wingko.

Dok: penulis

Bentuk subsistensi masyarakat Gunung Wingko telah berlangsung dari awal penghunian Situs Gunung Wingko hingga fase kehidupan yang berlangsung pada abad ke-17. Hal ini membuktikan bahwa bentuk subsistensi ternyata tidak banyak dipengaruhi oleh beberapa rentang sejarah yang ada. Kenyataan ini menunjukan bahwa faktor yang paling dominan dalam pembentukan budaya di situs ini adalah faktor alam. Selama ratusan tahun masyarakat Gunung Wingko mengeksploitsi alam sebagai sumber matapencaharian mereka sebagai penambang garam (Nitihaminoto 2001).

Analisis geoarkeologi terhadap lapisan endapan tanah menunjukan adanya tiga tahap perkembangan deposisis lateral dan empat perkembangan deposisi vertikal. Perkembangan deposisi lateral menunjukan adanya dua kali pembentukan beting gisik yang dihuni oleh masyarakat Gunung Wingko masa lampau dan sebuah pembentukan beting gisik resen yang tidak ada hubungannya dengan kehidupan tersebut (Nitihaminoto 2001). 


\section{KEHIDUPAN SOSIAL MASYARAKAT SITUS GUNUNG WINGKO}

Situs Gunung Wingko merupakan salah satu situs masa prasejarah akhir yang memiliki temuan kubur. Selain situs kubur di pesisir lain seperti Plawangan, Anyer, dan Gilimanuk, Situs Gunung Wingko merupakan satu-satunya situs dengan temuan kubur yang berada di pesisir Jawa bagian Selatan (Nitihaminoto 2005). Data kubur yang ditemukan di situs ini menunjukan bahwa masyarakat Situs Gunung Wingko telah memiliki religi yang diyakini (lihat gambar 3). Religi masyarakat yang hidup pada fase pertama

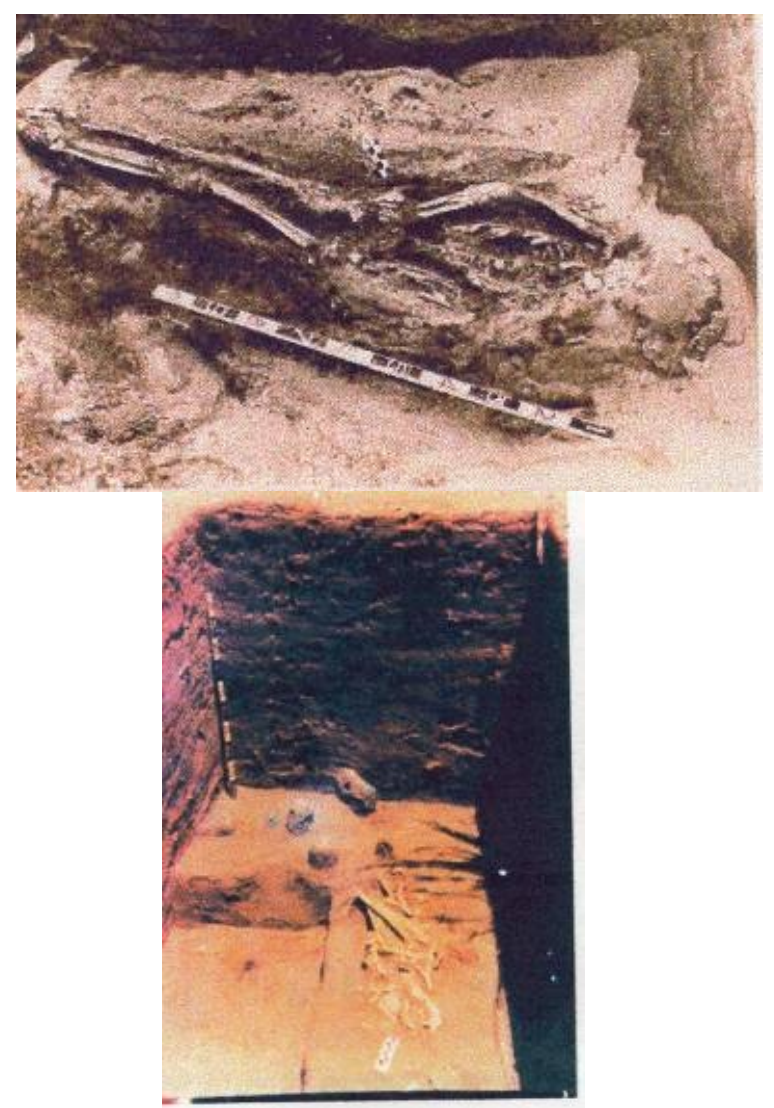

Gambar 3. Struktur kubur yang ditemukan dalam ekskavasi di Situs Gunung Wingko. Dok:Balar YK

adalah pengkultusan terhadap matahari. Hal ini dapat dilihat dari orientasi kubur yang diarahkan ke timur. Pada fase kehidupan kedua terjadi perubahan keyakinan, yaitu bahwa roh para leluhur berasal dari arah utara, selain itu diketahui pula adanya pemujaan terhadap gunung sebagai tempat bersemayamnya para roh nenek moyang atau tempat bersemayamnya para dewa (Wales 1953 dalam Nitihaminoto 2005). Dalam menjalankan kebutuhan religinya, masyarakat Situs Gunung Wingko menggunakan sarana berupa gerabah berbentuk kendi gogok (lihat foto 2), klenting (semacam periuk), dan pengaron (Nitihaminoto 2001)

Gambaran tentang kehidupan masyarakat Situs Gunung Wingko tercermin pula dari data bekal kubur yang ditemukan bersama rangka manusia. Bekal kubur yang biasa disertakan bersama rangka berrupa kendi gogok, mangkok gerabah, manik-manik, perhiasan perunggu, Adanya perbedaan bekal kubur dari rangka yang satu dan yang lainnya mengindikasikan adanya strata sosial dalam masyarakat.

Selain dari bekal kubur, kehidupan sosial masyarakat Situs Gunung Wingko juga tercermin dari prilaku mutilasi gigi. Ditemukannya rangka manusia dengan gigi seri yang dipangkas/dipangur dapat menunjukan adanya sebuah ritual dalam kehidupan seseorang sebagai bagian dari anggota komunitas Situs Gunung Wingko. Beberapa temuan artefak yang menggunakan bahan baku yang tidak tersedia di sekitar situs, seperti artefak logam, menunjukan bahwa masyarakat Gunung Wingko telah melakukan interaksi dengan masyarakat luar. Interaksi tersebut dapat berupa aktivitas perdagangan.

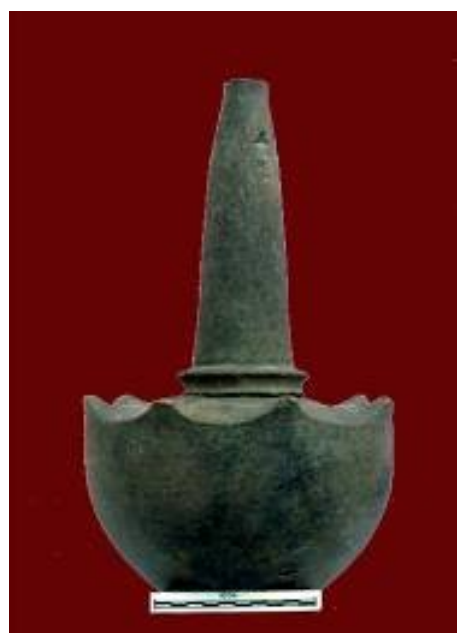

Foto 2. Kendi gogok yang ditemukan di Situs Gunung Wingko. Dok:Balar YK 
Sejauh ini penelitian yang dilakukan di Situs Gunung Wingko tidak menemukan bukti adanya mata uang, sehingga diduga aktivitas perdagangan yang dilakukan di tempat tersebut masih berupa barter. Barter dilakukan untuk memenuhi kebutuhan masyarakat yang tidak mampu mereka penuhi sendiri. Masyarakat Gunung Wingko selaku pembuat garam dan menukarkan hasil panen mereka dengan berbagai kebutuhan sehari-hari dan juga perlengkapan lainnya.

\section{GUNUNG WINGKO SAAT INI}

Pertumbuhan jumlah penduduk dan tingginya pengalihan lahan di sekitar situs sedikit banyak telah mengakibatkan terancamnya Situs Gunung Wingko. Saat ini jika kita berada di sekitar situs sudah sulit dijumpai data-data sesuai yang pernah dihasilkan pada penelitian sebelumnya baik berupa sebaran artefak gerabah maupun data penguburan. Sebagian penduduk bahkan tidak mengetahui akan keberadaan Situs Gunung Wingko, karena para penghuni lahan sebagian besar merupakan pendatang. Lahan-lahan yang dulunya merupakan beting gisik tanpa bangunan saat ini sudah menjadi area pemukiman yang dipenuhi bangunan permanen. Penduduk yang menempati wilayah tersebut beberapa di antaranya merupakan pendatang yang memperoleh lahan tersebut dengan cara membeli. Sebagian besar penduduk saat ini terutama generasi muda tidak memahami keberadaan situs. Ketika ditemukan artefak atau bahkan rangka manusia saat dilakukan penggalian tanah untuk keperluan pembangunan, maka masyarakat kemudian memindahkan temuan tersebut dan dikubur di tempat lain. ${ }^{1}$

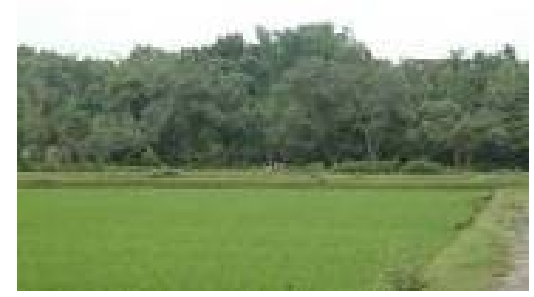

Foto 3. Lingkungan Situs Gunung Wingko saat ini (dilihat dari arah selatan). Dok:Irfanudid Wahid ${ }^{1}$ Wawancara dengan Bapak Mujimin (warga Desa Sanden yang
pernah terlibat dalam kegiatan penelitian) pada bulan Mei 2011

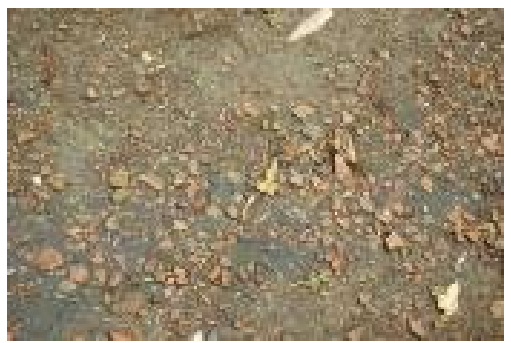

Foto 4. Sebaran fragmen gerabah Gunung Wingko yang bercampur dengan pecahan genteng rumah penduduk saat ini. Dok: Irfanudin Wahid

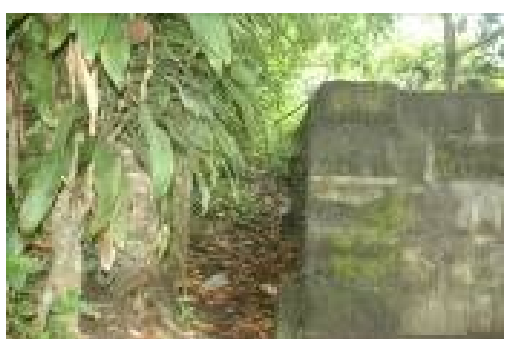

Foto 5. Salah satu situs penguburan yang saat ini sudah ditumbuhi bangunan permanen. Dok: Irfanudin Wahid

Lahan Situs Gunung Wingko sampai saat ini belum ditetapkan sebagai kawasan Cagar Budaya, sehingga dalam upaya pelestariannya masih belum memiliki kekuatan hukum. Menurut UU cagar budaya no. 11 tahun 2010, sebagai salahsatu upaya pelestarian cagar budaya harus dilakukan penetapan. Penetapan adalah pemberian status Cagar Budaya terhadap benda, bangunan, struktur, lokasi, atau satuan ruang geografis yang dilakukan oleh pemerintah kabupaten/kota berdasarkan rekomendasi Tim Ahli Cagar Budaya. 
Kondisi situs yang merupakan situs terbuka dan tanpa tinggalan bangunan monumental membuat keberadaan situs ini tidak banyak diketahui. Ditambah lagi tanpa adanya papan informasi atau penunjuk akan mempercepat hilangnya situs. Berbeda halnya dengan situs yang memiliki bangunan monumental, upaya pelestarian dan pemanfaatannya akan lebih terlihat pengembangan wisata alam, budaya, dan perikanan.

Situs Gunung Wingko sendiri terletak di kawasan yang direncanakan sebagai kawasan pengembangan wisata alam, budaya, dan perikanan. Pengembangan kawasan ini tentu saja akan berpengaruh negatif bila tidak sejalan dengan upaya pelestarian situs.

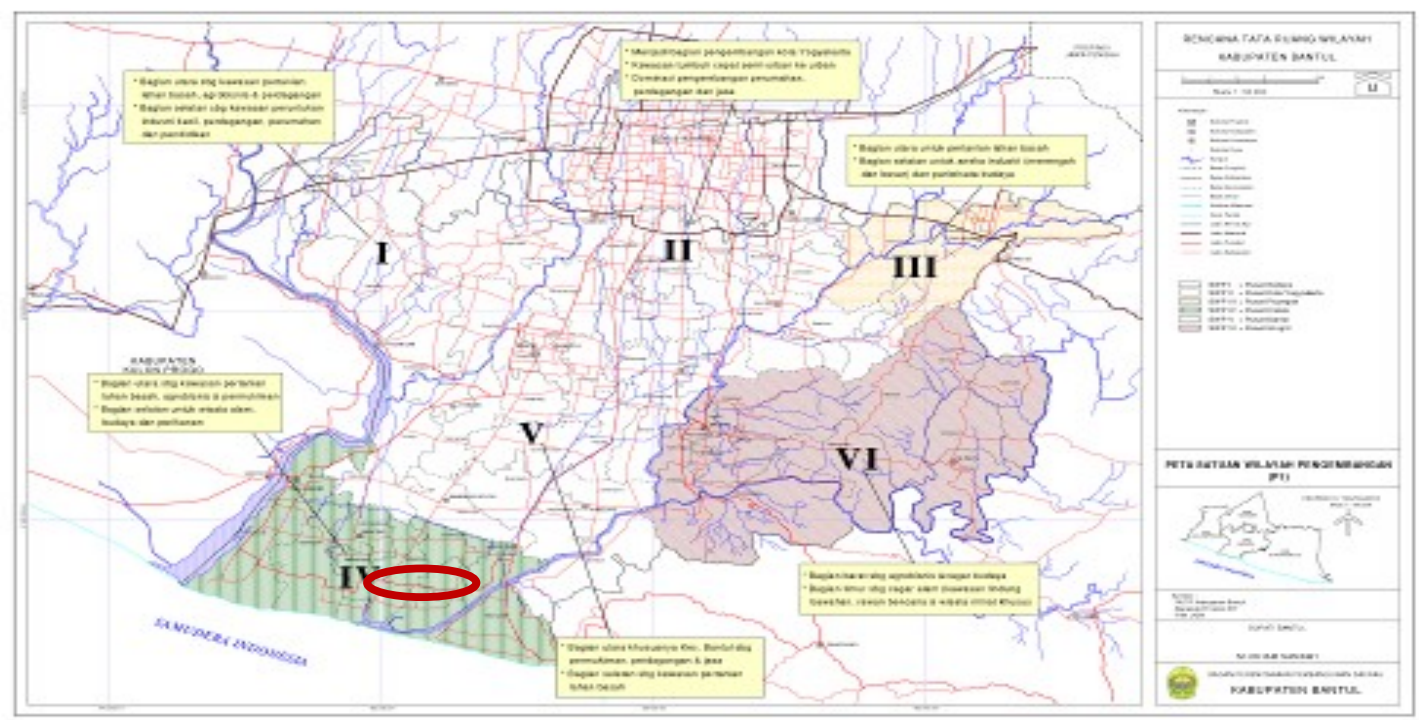

Peta 1. Lokasi Situs Gunung Winngko dalam peta RTRW Kabupaten Bantul. Sumber : www.docstoc.com

nyata karena objeknya terlihat. Situs terbuka tanpa bangunan monumental selain rentan terhadap kerusakan karena faktor alam seperti erosi, banjir, tanah longsor dan lain-lain, juga terancam oleh ketidaktahuan masyarakat. Masyarakat tidak atau belum familier dengan nilai penting dari objek yang memiliki nilai arkeologis dan historis seperti sebaran fragmen gerabah, maupun sisa penguburan. Hal ini terjadi sebagai akibat kurangnya informasi yang disampaikan baik berupa sosialisasi hasil penelitian maupun publikasi hasil penelitian.

Dalam peta rencana tata ruang wilayah (RTRW) Kabupaten Bantul disebutkan bahwa wilayah Kecamatan Sanden dan Kretek bagian utara masuk dalam kawasan pertanian lahan basah, agrobisnis dan pemukiman. Bagian selatan masuk dalam kawasan

\section{PEMANFAATAN HASIL PENELITIAN}

Penelitian arkeologi seyogyanya menjadi leading sekctor dalam upaya pelestarian dan pengembangan sumber daya arkeologi (Gunadi 2009). Hasil penelitian arkeologi merupakan dasar untuk upaya pemanfaatan dan pelestarian. Penelitian di Situs Gunung Wingko sejauh ini sudah menghasilkan pengetahuan yang cukup signifikan dalam rangka rekonstruksi sejarah kehidupan di situs ini. Namun terhadap hasil penelitian yang sudah dilakukan saat ini belum ada upaya untuk pemanfaatan maupun pelestarian baik secara fisik maupun secara informasi.

$$
\text { Keberadaaan sumberdaya }
$$
arkeologi akan selalu terkait langsung dengan kepentingan masyarakat baik secara lokasional, ikatan emosional, 
ataupun ikatan-ikatan yang bermuatan ekonomis. Selain itu masyarakat akan membutuhkan maupun memanfaatkan sumberdaya arkeologi baik untuk keperluan yang bersifat rekreatif maupun edukatif. Upaya pemanfaatan dan pelestarian sumberdaya arkeologi, agar dapat bertahan untuk masa yang akan datang, kadangkala memunculkan suatu konflik kepentingan karena sumberdaya arkeologi tersebut ditemukan pada suatu lokasi dengan sumberdaya lain (Gunadi 2001).

Hal ini terjadi pula di Situs Gunung Wingko. Kondisi situs yang berada di bentang alam terbuka dan tidak ada bangunan monumental yang ada sebagai "penanda" menjadikan "posisi" situs menjadi lemah. Untuk itu diperlukan suatu manajemen sumberdaya arkeologi yang tepat agar potensi sumberdaya arkeologi tetap dapat dipertahankan seiring dengan pegembangan potensi yang lain. Managemen pengelolaan sumberdaya arkeologi tersebut harus selalu bertumpu pada upaya perlindungan, pengembangan dan pemanfaatan. Perlindungan dimaksudkan untuk mencegah agar aset budaya bangsa tidak mengalami kerusakan dan kehancuran, sehingga kita akan kehilangan selamanya. Pengembangan berarti bahwa sumberdaya arkeologi harus dijaga kualitas penampilannya dan dapat difungsikan terus seperti fungsi semula atau untuk fungsi lain yang sesuai dengan ketentuan undang-undang. Sementara pemanfaatan harus memberikan kegunaan bagi peningkatan kesejahteraan masyarakat, baik untuk pendidikan dan pengembangan ilmu pengetahuan, ekonomi, maupun kebudayaan di masa kini dan mendatang.

Pelestarian dan pemanfaatan sumberdaya arkeologi merupakan dua elemen yang tidak dapat dipisahkan. Sumberdaya arkeologi harus dilestarikan supaya dapat dimanfaatkan untuk kepentingan saat ini dan yang akan datang. Pelestarian dilakukan dengan memadukan aspek fisik dan nonfisik. Aspek fisik meliputi kegiatan nyata akan pelestarian benda sumberdaya arkeologi, sedangkan aspek non fisik adalah bagaimana menumbuhkan rasa memiliki terhadap sumberdaya arkeologi tersebut. Pengertian dan pemahaman yang baik akan pengelolaan berbasis pelestarian sangat diperlukan, sehingga dapat meningkatkan nilai sumberdaya arkeologi dengan menyeimbangkan antar kepentingan sehingga tidak terjadi konflik kepentingan.

Sumberdaya arkeologi mempunyai nilai penting sehingga perlu untuk dilestarikan. Nilai penting yang terkandung tidak sama antar sumberdaya arkeologi. Menurut Daud Aris Tanudirdjo (2004) nilai penting yang terkandung dalam sumberdaya arkeologi antara lain : a). Nilai penting sejarah, dapat diukur dari kemampuan sumberdaya arkeologi untuk menjadi bukti yang berbobot dari kehidupan masa prasejarah, sejarah, atau peristiwa tertentu yang bersejarah, termasuk sejarah ilmu pengetahuan. b). Nilai penting ilmu pengetahuan, sumberdaya arkeologi mempunyai nilai penting bagi ilmu pengetahuan jika mempunyai potensi untuk diteliti lebih lanjut dalam menjawab masalah-masalah dalam bidang keilmuan. c). Nilai penting estetika, berkaitan dengan aspek keinderaan (sensory), sehingga harus mempertimbangkan keserasian hubungan antara bentuk, ukuran (scale), warna, tekstur, bahan, bau, serta suara dengan lokasi dan pemanfaatannya. Apabila nilai estetis ini masuk dalam konteks saujana (landscape) dapat pula dinilai kemampuannya untuk menyajikan pemandangan yang mengesankan (scenic or visual quality), untuk membangkitkan perasaan khusus bagi masyarakat, untuk memberikan makna tertentu bagi masyarakat, menumbuhkan rasa keterikatan dengan tempat tersebut, dan merupakan paduan serasi antara alam dan budaya manusia. d). Nilai penting sosial, meliputi kemampuan sumberdaya budaya untuk menumbuhkan perasaan rohaniah, spiritual, kebanggaan, kebangsaan, politis, dan perasaan budaya lainnya bagi kelompok mayoritas maupun kelompok minoritas.

Dalam konteks ini keberadaan Situs Gunung Wingko dapat dipandang 
sebagai tempat yang memiliki nilai penting secara sejarah, ilmu pengetahuan, dan nilai penting sosial. Sebagai sebuah situs, Gunung Wingko merupakan salahsatu bukti perkembangan pencapaian budaya dari masa prasejarah hingga masa sejarah. Konsistensi dari pola subsistensi juga menunjukan bahwa potensi sumberdaya alam di kawasan ini cukup besar sehingga mampu menyediakan "kebutuhan" masyarakat dari generasi ke generasi yang mencapai kurun waktu 2000 tahun. Berhentinya aktivitas penambangan garam pada masa penghunian Situs Gunung Wingko dimungkinkan karena pergeseran garis pantai yang disebabkan oleh aktivitas angin dan aktivitas marin.

Berdasarkan hasil penelitian etnografi, menunjukan bahwa setelah penghunian Situs Gunung Wingko berakhir, masyarakat di sekitar situs kembali melakukan aktivitas pembuatan garam, namun pada masa perang dunia ke-II yaitu pada sekitar tahun 1940-an aktivitas pembuatan garam di tempat ini terhenti, karena segala kegiatan pribumi yang berada di wilayah pantai selatan dilarang oleh Jepang (Nitihaminoto 2001).

\section{BENTUK PEMANFAATAN SITUS GUNUNG WINGKO}

Penelitian yang telah dilakukan secara intensif dan terus menerus telah menghasilkan informasi yang berkaitan dengan rekonstruksi kehidupan sosial budaya masyarakat di Situs Gunung Wingko sejak awal masehi hingga abad ke-17. Beberapa hasil budaya masyarakat Situs Gunung Wingko dapat digali dan dikembangkan lagi pada masa kini.

Nilai penting yang telah dirumuskan dari hasil penelitian yang pernah dilakukan seyogyanya ditindaklanjuti dengan upaya pelestarian baik secara material maupun informasi. Pendirian museum lapangan sebagai sarana representasi dokumen kehidupan masa lalu pada masyarakat Gunung Wingko perlu untuk dilakukan. Hal ini sebagai media informasi dan transfer pengetahuan sejarah kepada generasi kini dan mendatang. Selain memiliki fungsi pendidikan, pendirian museum lapangan yang representatif juga dapat meningkatkan apresiasi masyarakat terhadap akar budaya mereka. Pembangunan museum lapangan sebaiknya mengekspose bukti insitu datadata yang ditampilkan. Pendirian museum lapangan harus mengacu pada keputusan menteri Kebudayaan Dan Pariawisata Nomor KM.33/PI.303/MPK/2004 tentang museum. Diantara ketentuan umum dalam keputusan menteri tersebut disebutkan bahwa pendirian museum situs purbakala harus dapat dimanfaatkan untuk kepentingan ideologi, akademis, dan ekonomis. Kemudian koleksi museum situs harus berupa temuan, hasil penelitian, dan benda yang berasal dari situs tersebut. Koleksi yang berasal dari situs lain harus berupa temuan yang memiliki hubungan dengan situs tempat didirikannya museum (Siswanto 2011). Sehingga, museum yang dibangun tidak hanya sekedar tempat untuk memajang artefak, namun juga diharapkan mampu memvisualkan data dan informasi yang sesungguhnya. Jika pendirian museum terkendala oleh persayaratan peraturan yang harus dipenuh, maka pendirian pusat informasi dapat menjadi alternatif yang dapat dilakukan yang fungsinya kurang lebih sama dengan museum.

Menghidupkan kembali aktivitas pembuatan garam merupakan salahsatu bentuk museum lapangan yang diusulkan. Hal ini selain dapat menjadi bukti visual budaya dan tradisi yang pernah ada, hidupnya kembali aktivitas membuat garam dapat meningkatkan pendapatan masyarakat, juga dapat menjadi sebuah atraksi wisata yang dapat dikembangkan. Sejauh ini aktivitas pembuatan garam di sepanjang pantai selatan Jawa masih belum ada, sehingga kegiatan ini menjadi sangat menarik. 


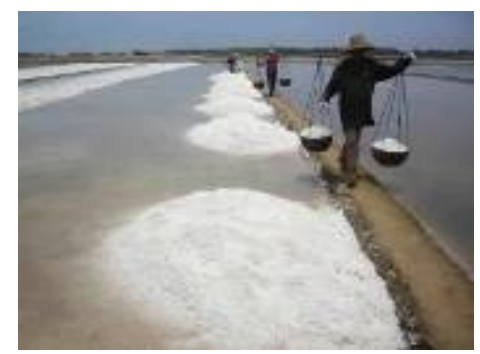

Foto 6. Ilustrasi pembuatan garam tradisional Sumber:kabar-indramayu.blogspot.com

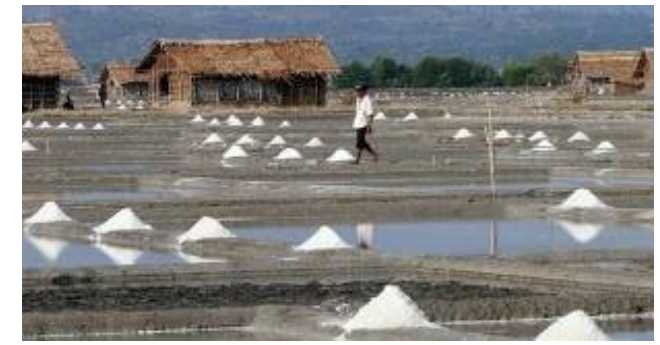

Foto 7. Ilustrasi lahan penambangan garam dan beberapa bangunan semipermanen

Sejalan dengan penetapan kawasan selatan Bantul yang dikembangkan menjadi daerah tujuan wisata alam dan budaya, upaya menghidupkan kembali aktivitas pembuatan garam dapat menjadi alternatif tujuan wisata yang dapat dinikmati oleh wisatawan. Sesuai dengan pengertian wisata budaya, yaitu sebagai suatu perjalanan yang dilakukan atas dasar keinginan untuk memperluas pandangan hidup seseorang dengan jalan mengadakan kunjungan atau peninjauan ke tempat lain untuk mempelajari keadaan rakyat, kebiasaan dan adat istiadatnya, cara hidup serta budaya dan seni mereka (Pendit 1994), maka menghidupkan kembali aktivitas pembuatan garam dapat menjadi semacam living museum yang mampu memberi informasi yang dikaitkan dengan keberadaan museum dengan koleksi artefak hasil penelitian dari Situs Gunung Wingko.

Selama ini destinasi wisata yang ada di kawasan ini adalah Pantai Samas serta wisata budaya berupa upacara Kirab Tumuruning Maheso Suro dan Labuhan Sedekah Laut yang diadakan setiap satu tahun sekali oleh Keraton Kasultanan Yogyakarta untuk memperingati tanggal satu Suro.
Dari sisi akademis, Upaya sosialisasi dan transfer pengetahuan kepada generasi muda pun perlu untuk dilakukan. Memasukan materi tentang sejarah masyarakat Situs Gunung Wingko dalam materi pelajaran untuk muatan lokal dapat digunakan sebagai upaya untuk memperkuat pengetahuan dan menumbuhkan rasa memiliki sehingga upaya pelestarian akan muncul dari masyarakat itu sendiri. Pengenalan kesejarahan situs kepada murid melalui pelajaran sekolah merupakan salahsatu cara penanaman pengetahuan sehingga diharapkan sejak dini masyarakan sudah mulai "familiar" dengan potensi yang ada disekitar mereka.

Beberapa upaya pemanfaatan yang diusulkan tersebut tentu saja memiliki beberapa persoalan yang perlu dipecahkan. Status lahan situs Gunung Wingko yang belum memiliki kekuatan hukum tentu saja menjadi kendala tersendiri, lebih lagi deliniasi yang tidak jelas. Diperlukan kebijakan lintas sektoral dalam hal ini dari pemerintah daerah selaku "pemilik lahan", Balai Arkeologi Yogyakarta selaku instansi yang telah melakukan penelitian di situs, BPCB DIY serta masyarakat sekitar selaku pihak yang sehari-hari "bergelut" dengan situs.

\section{UCAPAN TERIMAKASIH}

Penulis ingin mengucapkan terima kasih kepada:

1. Dr. Goenadi Nitihaminoto, yang telah mengijinkan penulis untuk mengakses segala data dan hasil penelitian di Situs Gunung Wingko.

2. Irfanudin Wahid Marzuki, MA yang telah membantu penulis dalam melakukan observasi lapangan di Situs Gunung Wingko. 


\section{DAFTAR PUSTAKA}

Alifah, 2012. "Jejak Industri Kerajinan dalam Artefak Gerabah". Mata Jendela Seni Budaya Yogyakarta. Vol VII no 4. Yogyakarta: Taman Budaya.

Kasnowiharjo, Gunadi, 2001. Manajemen Sumberdaya Arkeologi. Makasar: Lembaga Penerbitan Universitas Hasanuddin.

2009. "Penelitian Arkeologi yang Implementatif: Suatu Obsesi Hasil Penelitian Arkeologi Masa Depan" dalam Walennae. Makasar: Balai Arkeologi Makasar.

Nitihaminoto, Goenadi, 2001. Situs Gunung Wingko: Sebuah Rekonstruksi Kehidupan Masyarakat Akhir Perundagian. Disertasi. Fakultas Pascasarjana. Yogyakarta: Universitas Gadjah Mada.

Nitihaminoto, Goenadi, 2005. "Struktur Kubur Masa Prasejarah Akhir di Situs Gunung Wingko" dalam Jurnal Penelitian Arkeologi No. 5. Yogyakarta: Balai Arkeologi Yogyakarta.

Pendit, Nyoman S, 1994. Ilmu Pariwisata Sebuah Pengantar Perdana. Jakarta: Pradnya Paramita

Siswanto, 2011. Pengelolaan Situs Hominid Patiayam Kudus Jawa Tengah: Nilai Penting dan Peran Para Pihak dalam Pengelolaan Situs Berbasis Masyarakat. Tesis. Yogyakarta: Prodi Arkeologi UGM.

Suprajaka, 1989. Morfogenesis dan Pedogenesis Bentang Lahan Delta Progo. Skripsi. Yogyakarta: Fakultas Geografi UGM.

Tanudirjo, Daud Aris, 2003. Warisan Budaya Untuk Semua: Arah Kebijakan Pengelolaan Warisan Budaya Indonesia Di Masa Mendatang. Bukittinggi. Makalah yang disampaikan dalam Konggres Kebudayaan V. 